\section{Under the ocean}

Peter J. Smith

The Sea Floor: An Introduction to Marine Geology.

By E. Seibold and W.H. Berger.

Springer-Verlag: 1982. Pp.288. DM46, \$20.

SEIBOLD and Berger are in an unenviable position. They have come out with a 288-page introduction to marine geology within a year of the publication of an 813-page book with precisely the same aim and written by one of the world's bestknown oceanographers. Moreover, the earlier book, James Kennett's Marine Geology (Prentice-Hall, 1982), though not flawless, has been universally praised, not least by myself (Nature 295, 466; 1982). Then it has to be said that The Sea Floor has been "developed" (the authors' word) from a previous book in German by Seibold, which means that the present version was not planned from the start as a coherent whole and is in large part a translation.

The book opens with chapters on the origin and morphology of ocean basins and margins, and continues with discussions of the sources and composition of marine sediments, the effects of waves and currents, sea level changes, and organisms on the sea floor. It then moves on to the effect of climatic zoning on marine sedimentation and to palaeoceanography, ending, apart from a number of appendices, with a chapter on ocean floor resources.

The approach is straightforward, if somewhat uninspiring, and the content is not always as up-to-date as it might be. Among the intended audience are those "without formal training in the natural sciences"; but it is hard to take that very seriously, partly because there is little attempt at the beginning to set up marine geology as a topic worthy of the nonscientist's attention and partly because absolutely no effort has been made to present the book as anything other than a dull academic text.

Apart from price, the volume's one advantage over its rival is that it is a short, no-frills summary of marine geology and thus potentially useful to someone - an undergraduate, say - wanting a quicklyread overview of the subject before getting down to serious study. Even in this it is not ideal, however, because of its omissions, one of the most conspicuous of which is treatment of igneous petrology and geochemistry.

The Sea Floor must have seemed a good idea when it was proposed; the marine geology field was then almost free of introductory texts. It is the authors' misfortune to have been thoroughly trounced by Kennett.

Peter J. Smith is Reader in the Department of Earth Sciences at the Open University.

\section{Pictures of petrology}

\section{Bernard Elgey Leake}

Elsevier's Mineral and Rock Table.

Compiled by P. Lof.

Elsevier Scientific: 1982. Dfl.40. Ten copies Dfl.185, \$78.75.

ThIS large $(70 \times 133 \mathrm{~cm})$ wall-chart displays a wealth of information concerning the microscopic properties of igneous, metamorphic, sedimentary and orecontaining rocks.

The top two-thirds of the chart deals with the optical properties of minerals, arranged in six columns of rock-forming minerals (totalling 74 minerals) plus four columns of ore minerals (totalling 50). The former are classified by birefringence, colour and relief and are accompanied by a superbly-printed pair of colour photographs of each mineral in plane-polarized light and under crossed-nicols. Similarly with the ore minerals, which are classified according to anisotropy, isotropy, distinctive internal reflections and reflectance properties; again a pair of colour photographs shows each mineral under plane polarized light and crossed-nicols.

The photographs, totalling about 225 , are the highlight of the chart. Their quality is excellent and the choice of representative views is astute. Even muscovite and talc, which are effectively indistinguishable in thin section, are placed next to each other so that their similarity is apparent. Unfortunately, though, the obsolete terms oxyhornblende and barkevikite are retained.

The lower third of the poster diagrammatically shows the principal rock, meteorite and ore classifications, and includes a coloured birefringence chart.

The poster is intended for laboratories where students are working with microscopes and endeavouring to master mineralogy and petrology, but it will certainly also be helpful for graduate students and invaluable in tutorials. For all such users it can be strongly recommended.

Bernard Elgey Leake is Professor of Geology at the University of Glasgow, and Honorary Keeper of the Geological Collections in the Hunterian Museum.

\section{Spring books}

The next review supplement to appear in Nature will be Spring books, on April 28th. Among the books to be reviewed are Nicholas Wade and William Broad's Betrayers of the Truth: Fraud and Deceit in the Halls of Science, Dorothy Nelkin's The Creation Controversy, Science and Moral Priority by Roger Sperry, and Stephen Jay Gould's latest collection of essays, Hen's Teeth and Horse's Toes.

\section{Pet rock-pourri}

\section{Bruce Sellwoood}

Sedimentary Structures.

By J.D. Collinson and D.B. Thompson.

George Allen \& Unwin: 1982. Pp.240.

$H b k £ 18, \$ 40 ; p b k$ £8.95, \$17.95.

Sedimentary Petrology.

By Harvey Blatt.

W.H. Freeman: 1982. Pp.564.

Hbk \$22.50, £22.20; pbk \$14.

Petrology: Igneous, Sedimentary and

Metamorphic.

By Ernest G. Ehlers and Harvey Blatt.

W.H. Freeman: 1982. Pp. 731.

$\$ 29.95$, f22.20.

Igneous and Metamorphic Petrology.

By Myron G. Best.

W.H. Freeman: 1982. Pp. 630.

$\$ 29.95, £ 22.20$.

Igneous Petrology. By C.J. Hughes.

Elsevier Scientific: 1982. Pp.550. Dfl.70, \$30.

THE complex mineral aggregates dismissed by the world at large as merely "rocks" are generally subdivided into sedimentary, metamorphic and igneous depending upon their origin. Sedimentary rocks are usually bedded and sometimes exhibit a variety of internal structures, and biogenic features, produced in response to processes acting at the time of deposition. The successful interpretation of sedimentary sequences depends on the acquisition of field data and its integration with later laboratory studies. There are, however, few elementary texts providing guidance on how field observations may be made or, indeed, on what pertinent questions should be asked in the face of an unknown outcrop.

Sedimentary Structures is essentially a teaching book designed, with the British undergraduate in mind, to fill this gap. It does so most successfully. As well as taking for granted that the reader possesses a basic knowledge of mineralogy and other sciences, the assumption is also made that he or she will regularly get wet and dirty, as all sedimentologists do.

It is a well organized book, commencing with a discussion on the nature of the bedding itself. (A rock sequence may represent some millions of years of time and yet contain individual beds that took merely hours or tens of thousands of years to accumulate.) Successive chapters deal with the properties of fluids and sediments, erosional structures, mudrocks, sandstones, gravels, chemical and biological structures and deformational structures. The final chapter indicates how observations can be assembled into depositional interpretations of sedimentary sequences and facies. Most topics are successfully considered with the exception of mudrocks. This book is excellent value, however, and can be recommended for students without serious reservation.

The remaining books deal with petro- 